\title{
KCNQ1 A340E impairs electrolyte homeostasis independently of the renin-angiotensin- aldosterone system in mice
}

\author{
Q. Pan*, Y. Sang*, C. Sun, G. Li and Y. Wang \\ Department of Gastroenterology, Xinhua Hospital, School of Medicine, \\ Shanghai Jiao Tong University, Shanghai, China \\ *These authors contributed equally to this study. \\ Corresponding authors: Q. Pan / Y. Wang \\ E-mail: pan_qin@yeah.net / wangyvqin00@sina.com
}

Genet. Mol. Res. 15 (3): gmr.15038802

Received May 16, 2016

Accepted June 3, 2016

Published July 25, 2016

DOI http://dx.doi.org/10.4238/gmr.15038802

Copyright $(92016$ The Authors. This is an open-access article distributed under the terms of the Creative Commons Attribution ShareAlike (CC BY-SA) 4.0 License.

\begin{abstract}
KCNQ1 (KvLQT1) is the pore-forming $\alpha$-subunit of the potassium channel. To uncover its role in electrolyte metabolism, we investigated the effects of KCNQ1 A340E, a loss-of-function mutant, on J343 mice. Compared with the normal controls (C57BL/6J mice) bearing the wild-type KCNQ1 gene, J343 mice bearing KCNQ1 A340E demonstrated a much higher 24-h intake of electrolytes (potassium, sodium, and chloride). However, they suffered from significant electrolyte loss through both the feces and urine during a period of $24 \mathrm{~h}$. Unbalance in electrolyte metabolism disrupted the electrolyte homeostasis in the $\mathrm{J} 343$ mice, which was characterized by the comparatively lower level of serum potassium (J343 vs C57BL/6J: $12.06 \pm 1.47 v s 14.44 \pm 3.58 \mathrm{mM}, \mathrm{P}=0.01)$ and higher levels of serum sodium (J343 vs C57BL/6J: $148.05 \pm 4.47$ vs $115.15 \pm 17.25 \mathrm{mM}, \mathrm{P}$ $\left.=4.20 \times 10^{-4}\right)$ and chloride $(\mathrm{J} 343$ vs C57BL/6J: $118.0 \pm 4.47$ vs 85.21 $\pm 11.90 \mathrm{mM}, \mathrm{P}=2.47 \times 10^{-5}$ ). Between the $\mathrm{J} 343$ and $\mathrm{C} 57 \mathrm{BL} / 6 \mathrm{~J}$ mice,
\end{abstract}


there was no statistically significant difference in KCNQ1 expression in the gastrointestinal tract and kidney. Normal concentrations of plasma renin, angiotensin I, and aldosterone were also detected in both lines of mice. KCNQ1, therefore, is suggested to play a central role in electrolyte metabolism. KCNQ1 A340E, with the loss-of-function phenotype, may dysregulate electrolyte homeostasis in mice independently of the activity of the renin-angiotensin-aldosterone system.

Key words: KCNQ1; Mutation; Electrolyte; Homeostasis; Mice

\section{INTRODUCTION}

KCNQ1 (KvLQT1) is the pore-forming $\alpha$-subunit of the outwardly rectifying voltagedependent potassium channel, with six transmembrane domains and a single pore-loop (Robbins, 2001). Together with the KCNEs (minimal potassium-channel proteins, $\beta$-subunit), KCNQ1 enables a potassium current that exerts pivotal physiological actions in electrical repolarization of the cell membrane. A wide variety of cellular functions related to the KCNQ1-derived current, including synaptic transmission, heart action potential, and muscle excitability, have been well established (Sanguinetti et al., 1996; Robbins, 2001). In contrast, mutations in the KCNQ1 gene have been associated with human Romano-Ward or long QT syndrome (OMIM: No. 192500) (Amin et al., 2012), Jervell and Lange-Nielsen syndrome (OMIM: No. 220400) (Sung et al., 2014), familial atrial fibrillation (Das et al., 2009), and atrioventricular block (Yang et al., 2007).

Recently, KCNQ1 expression has been discovered in nephron segments of the kidney, including renal epithelia of the late proximal tubule (PT), distal convoluted tubule (DCT), connecting segment (CNT), collecting ducts (CD), and glomeruli (Wang, 2004; Zheng et al., 2006). It is likely to play a role in stabilizing the membrane potential of tubular cells and then regulating electrolyte reabsorption (Vallon et al., 2001, 2005; Lang et al., 2007). Moreover, when KCNQ1 localizes along the gastrointestinal tract (GIT), particularly the stomach, crypt cells of small intestine, and colon (Dedek and Waldegger, 2001; Kunzelmann, et al., 2001a,b; Heitzmann et al., 2004), it assembles with KCNE3, and may form part of the cAMP-regulated $\mathrm{K}^{+}$current in colonic crypt cells and take part in transepithelial chloride secretion (Schroeder et al., 2000; Warth et al., 2002). Hence, KCNQ1 is suggested to regulate electrolyte metabolism via GIT-based ingestion and kidney-based excretion of electrolytes.

We, therefore, studied the C57BL/6J and J343 mouse lines that bear the wild-type and loss-of-function mutation (A340E) of KCNQ1, respectively. KCNQ1 expression in the stomach, intestine, cecum, colon-rectum, and kidney was compared between the two mouse lines. The electrolyte intake from the GIT and its excretion from the kidneys were then assessed to characterize the effect of KCNQ1 A340E on serum electrolyte homeostasis. Additionally, the plasma activity of the renin-angiotensin-aldosterone system (RAAS) in both mouse lines was studied by radioimmunoassay.

\section{MATERIAL AND METHODS}

\section{Mouse lines}

Adult males of the $\mathrm{J} 343$ mouse line $(19.13 \pm 1.93 \mathrm{~g}, \mathrm{~N}=10)$ bearing a loss-of-function 
mutation of KCNQ1 (A340E) (Casimiro et al., 2004) and those of the C57BL/6J mouse line ( $20.84 \pm 0.72 \mathrm{~g}, \mathrm{~N}=10$ ) bearing the wild-type KCNQ1 were used in the present experiments. Following the urine and fecal sampling studies, the mice were sacrificed and samples of the stomach, intestine, cecum, colon-rectum, and kidney were extracted.

All animal experimentations were approved by the ethical committee of Shanghai Jiaotong University, School of Medicine, and conducted in accordance with the National Institutes of Health Guide for the Care and Use of Laboratory Animals.

\section{Real-time polymerase chain reaction}

Total RNA, being extracted from different organs (tail, stomach, intestine, cecum, colon-rectum, and kidney) of mice, was treated according to the instructions of the ExScript RT reagent kit (TaKaRa, Kusatsu, Japan) for the real-time reaction. The real-time polymerase chain reaction was then performed by using SYBR Premix Ex Taq (TaKaRa) on a Light Cycler (Roche Diagnostics GmbH, Penzberg, Germany) instrument according to the manufacturer protocol. Primers for KCNQ1 (Forward primer: ACACTGCTGGAAGTAAGCAC; Reverse primer: TGCGCACCATAAGGTTCAGG) and GAPDH (endogenous control; Forward primer: CACGGCAAGTTCAACGGCACAGT;Reverseprimer:AGCGGAAGGGGCGGAGATGAT) were used as described previously (Guo et al., 2009; Fröhlich et al., 2011). Relative gene expression levels were calculated by the $2^{-\Delta \Delta C t}$ method.

\section{Western blot analysis}

Total protein from different organs (tail, stomach, intestine, cecum, colon-rectum, and kidney) of mice was extracted and quantified by the bicinchoninic acid method (Pierce, Rockford, IL, USA). Subsequently, each sample was subjected to the following procedures: 1) loading on $10 \%$ polyacrylamide gels; 2) electrophoretic separation; 3 ) transfer to polyvinylidine difluoride membranes; 4) blocking of the membranes with $0.1 \%$ Tween 20 in Tris-buffered saline containing 5\% non-fat dry milk; 5) reaction with primary antibodies (anti-KCNQ1 (ab183412, 1:500) and anti-GAPDH (ab9484, 1: 1000); Abcam, Cambridge, MA, USA) at $4^{\circ} \mathrm{C}$ overnight; and 6) reaction with horseradish peroxidase-conjugated goat anti-mouse IgG (1:3000; Jackson ImmunoResearch Laboratories, Inc., West Grove, PA, USA) at room temperature for $2 \mathrm{~h}$. After washing, the membranes were processed using SuperSignal West Pico Chemiluminescent Substrate (Pierce).

\section{Urine, fecal, and blood assays}

The $\mathrm{C} 57 \mathrm{BL} / 6 \mathrm{~J}(\mathrm{~N}=10)$ and $\mathrm{J} 343(\mathrm{~N}=10)$ mice were housed in metabolic cages (Harvard Apparatus, Holliston, MA, USA) and allowed free access to water and standard irradiated feed by gavage (Shanghai SLAC Laboratory Animal Co., China). After 2 days of adaptation to the metabolic cages, the 24-h urine, feces, and dietary intake of each group were recorded and urine and fecal samples were collected. Blood samples were also taken from both groups of mice.

The electrolyte intake of each mouse was calculated by analytical balance of its food consumption. The serum and urine concentrations of $\mathrm{Na}^{+}, \mathrm{K}^{+}$, and $\mathrm{Cl}^{-}$were determined on an Unicel DxC 800 (Beckman Coulter GmbH, Krefeld, Germany) apparatus, using the

Genetics and Molecular Research 15 (3): gmr.15038802 
conductivity electrode method. Additionally, the dried feces were grinded, soaked overnight in $2 \mathrm{~mL} 0.75 \mathrm{M} \mathrm{HNO}_{3}$, and subsequently subjected to $\mathrm{Na}^{+}, \mathrm{K}^{+}$, and $\mathrm{Cl}^{-}$assessment as described above.

\section{Radioimmunoassay for renin-angiotensin-aldosterone system activity}

The plasma concentrations of renin, angiotensin I, and aldosterone were analyzed by using radioimmunoassay kits (Northern Biochemical Institute, China), in accordance with the manufacturer protocol. In brief, for renin evaluation, the plasma samples were incubated with angiotensin $\mathrm{I}(\mathrm{AI})$ regulator at $37^{\circ} \mathrm{C}$ for $1 \mathrm{~h}$ and then reacted with $\left[{ }^{125} \mathrm{I}\right]$ label and $\mathrm{AI}$ antibody at $4{ }^{\circ} \mathrm{C}$ overnight. After separation using the donkey-anti-rabbit immune separator at room temperature for $15 \mathrm{~min}$, the pellet was collected by centrifugation ( $3500 \mathrm{rpm}, 15 \mathrm{~min}$ ) and its radioactivity in counts per minute (cpm) was detected. Finally, the difference of cpm values between the tested samples and the control samples, which reflected the renin production rate, was evaluated. Similarly, for angiotensin I and aldosterone evaluation, the plasma samples were incubated successively with $\left.{ }^{[25} \mathrm{I}\right]$ label, antibodies, and donkey-anti-rabbit immune separator as described above. Thereafter, the concentrations of angiotensin I and aldosterone in each sample were obtained by detection of the $\mathrm{cpm}$ value in the centrifuged pellet.

\section{Statistical analysis}

Data are reported as means $\pm \mathrm{SD}$. The independent $t$-test and ANOVA were applied for data analysis using SPSS 16.0. P values less than 0.05 were considered to be statistically significant. The tests were two-tailed.

\section{RESULTS}

\section{J343 mice bearing KCNQ1 A340E demonstrated no alternation in the expression of KCNQ1}

To highlight the effect of the A340E mutation on KCNQ1, the expression of KCNQ1 was tested in C57BL/6J and J343 mice at both the mRNA and protein levels. Transcriptionally, the mRNA level of KCNQ1 in J343 mice was parallel to that of C57BL/6J mice, no matter in the stomach, intestine, cecum, colon-rectum, and kidney (Figure 1A). Similarly, there was no significant difference in KCNQ1 expression in the GIT and urinary tract between the C57BL/6J and J343 mice (Figure 1B and C).

\section{KCNQ1 A340E increased the intake and loss of electrolytes}

Compared with the normal controls (C57BL/6J mice), the J343 mice exhibited a much higher 24-h intake of food containing potassium (J343 vs C57BL/6J: $86.35 \pm 27.21$ vs 57.53 $\pm 9.33 \mu \mathrm{mol}, \mathrm{P}=0.01$ ), sodium (J343 vs C57BL/6J: $133.23 \pm 41.98$ vs $88.76 \pm 14.39 \mu \mathrm{mol}, \mathrm{P}$ $=0.01)$, and chloride $(\mathrm{J} 343$ vs $\mathrm{C} 57 \mathrm{BL} / 6 \mathrm{~J}: 230.18 \pm 72.54$ vs $153.36 \pm 24.87 \mu \mathrm{mol}, \mathrm{P}=0.01)$ (Figure 2A).

Accordingly, there was significant difference between the J343 and C57BL/6J mice with regard to the 24-h fecal losses of sodium (J343 vs C57BL/6J: $22.40 \pm 15.66$ vs $12.68 \pm$ 
$\left.4.54 \mu \mathrm{mol}, \mathrm{P}=2.51 \times 10^{-3}\right)$ and chloride (J343 vs C57BL/6J: $30.45 \pm 10.68 \mu \mathrm{mol} v s 19.53 \pm$ $4.90 \mu \mathrm{mol}, \mathrm{P}=8.60 \times 10^{-4}$ ) (Figure $2 \mathrm{~B}$ ). Fecal loss of electrolytes was therefore indicated in mice bearing KCNQ1 A340E.

Another noticeable phenomenon lay in the increased urinary loss of electrolytes by the J343 mice. Per the values obtained, the J343 mice experienced statistically higher 24-h excretion of potassium, sodium, and chloride than the C57BL/6J mice (potassium: $147.69 \pm$ 99.00 vs $101.66 \pm 36.80 \mu \mathrm{mol}, \mathrm{P}=0.01$; sodium: $100.60 \pm 75.57$ vs $67.53 \pm 29.22 \mu \mathrm{mol}, \mathrm{P}=$ 0.01 ; chloride: $122.70 \pm 80.81$ vs $90.59 \pm 35.30 \mu \mathrm{mol}, \mathrm{P}=0.03$ ) (Figure $2 \mathrm{C}$ ). In addition, no statistical difference in glucose $(0.32 \pm 0.42$ vs $0.21 \pm 0.14 \mu \mathrm{mol})$ and urine volume output was observed between the $\mathrm{J} 343$ and $\mathrm{C} 57 \mathrm{BL} / 6 \mathrm{~J}$ mice $(0.75 \pm 0.62$ vs $0.54 \pm 0.26 \mathrm{~mL})$.

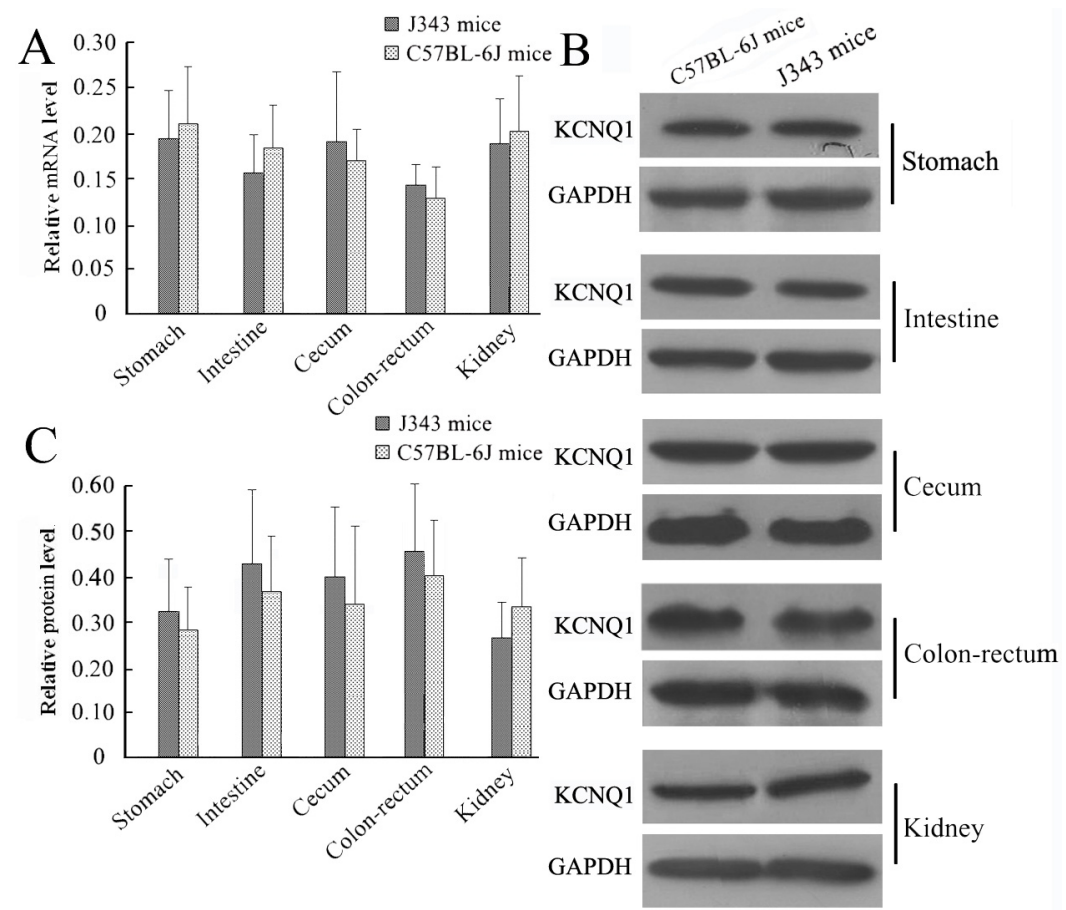

Figure 1. Effect of KCNQ1 A340E on KCNQ1 expression in the gastrointestinal tract and kidney. A. mRNA levels of KCNQ1 in the stomach, intestine, cecum, colon-rectum, and kidney of C57BL/6J and J343 mice. B. C. Western blot of KCNQ1 (B) and its relative protein levels $(\mathbf{C})$ in the stomach, intestine, cecum, colon-rectum, and kidney of $\mathrm{C} 57 \mathrm{BL} / 6 \mathrm{~J}$ and $\mathrm{J} 343$ mice.

\section{KCNQ1 A340E impaired the homeostasis of serum electrolytes}

When compared with the levels in the C57BL/6J mice, the J343 mice suffered from greatly decreased serum potassium levels (J343 vs C57BL/6J: $12.06 \pm 1.47$ vs $14.44 \pm 3.58$ $\mathrm{mM}, \mathrm{P}=0.01)$ and elevated levels of serum sodium (J343 vs $\mathrm{C} 57 \mathrm{BL} / 6 \mathrm{~J}: 148.05 \pm 4.47$ vs $\left.115.15 \pm 17.25 \mathrm{mM}, \mathrm{P}=4.20 \times 10^{-4}\right)$ and chloride $(\mathrm{J} 343$ vs $\mathrm{C} 57 \mathrm{BL} / 6 \mathrm{~J}: 118.00 \pm 4.47$ vs 85.21 $\pm 11.90 \mathrm{mM}, \mathrm{P}=2.47 \times 10^{-5}$ ) (Figure 2D). Therefore, the abnormal dynamics of electrolyte metabolism, mainly due to KCNQ1 A340E, led to the abolishment of electrolyte homeostasis in the J343 mice (Figure 3). 

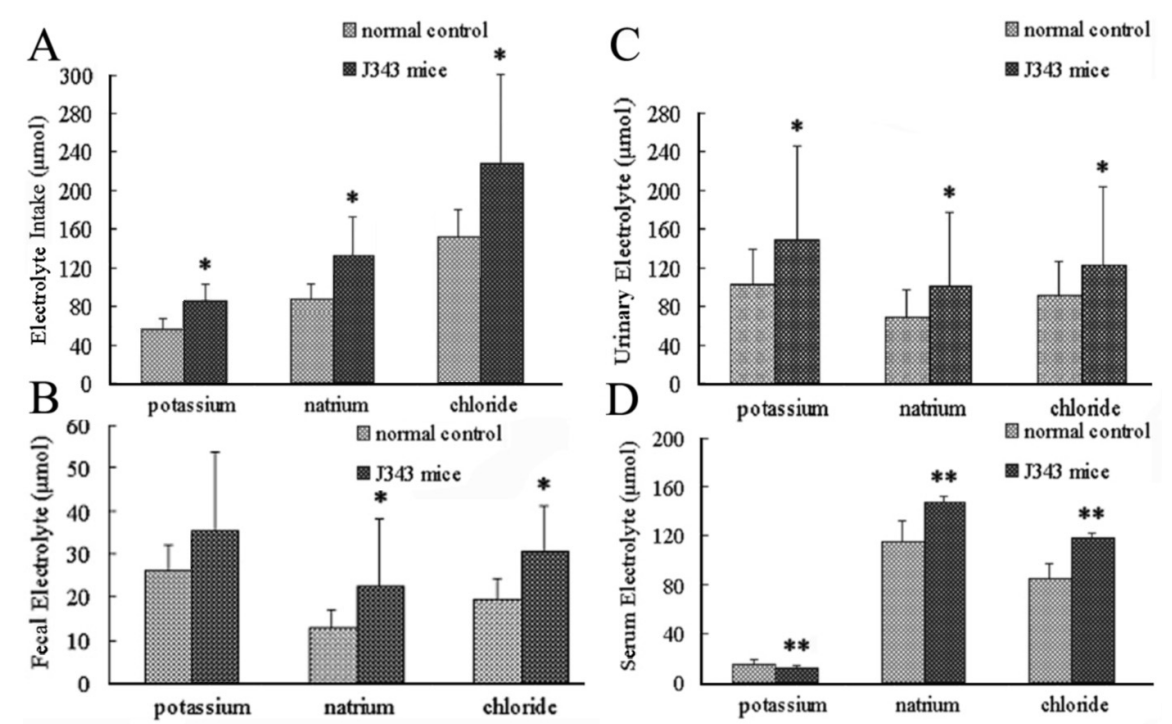

Figure 2. KCNQ1 A340E impaired the homeostasis of serum electrolytes on the basis of increased intake and loss of electrolytes. A. Dietary intake of electrolytes in C57BL/6J mice bearing wild-type KCNQ1 and in J343 mice bearing KCNQ1 A340E. B. C. Fecal (B) and urinary (C) losses of electrolytes in the C57BL/6J and J343 mice. D. Effect of KCNQ1 A340E on the serum level of electrolytes in C57BL/6J and J343 mice. Independent $t$ test was applied for data analysis. ${ }^{*} \mathrm{P}<0.05$ compared with $\mathrm{C} 57 \mathrm{BL} / 6 \mathrm{~J}$ mice. ${ }^{*} \mathrm{P}<0.01$ compared with $\mathrm{C} 57 \mathrm{BL} / 6 \mathrm{~J}$ mice.

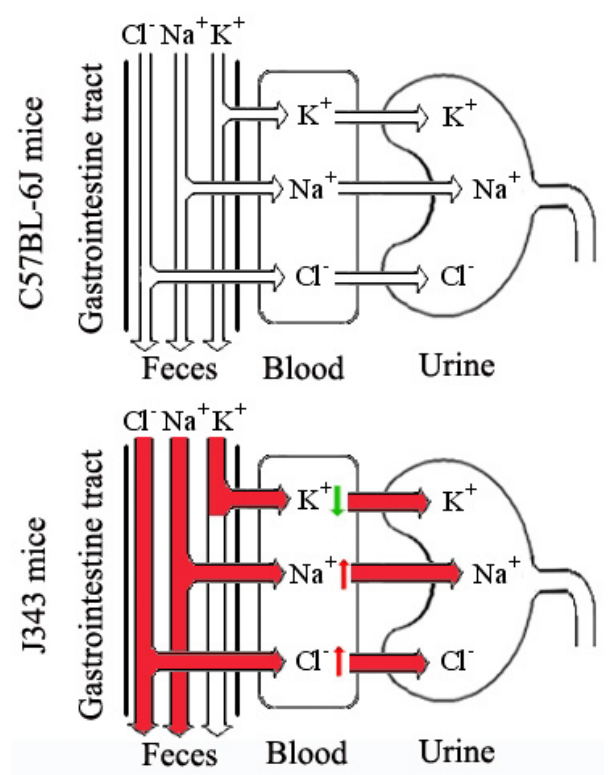

Figure 3. Schematic diagrams illustrating the effect of KCNQ1 A340E on electrolyte metabolism in J343 mice, as compared with the normal control $(\mathrm{C} 57 \mathrm{BL} / 6 \mathrm{~J})$ mice. Thick red arrows reflect the increased intake or loss of electrolytes. Thin red arrows reflect the increased serum level of electrolytes. Thin green arrow reflects the decreased serum level of $\mathrm{K}^{+}$.

Genetics and Molecular Research 15 (3): gmr.15038802 


\section{Normal RAAS activity characterized the KCNQ1 mutant mice}

Plasma concentrations of renin, angiotensin I, and aldosterone reflect the activity of the RAAS. According to the radioimmunoassay, the $\mathrm{J} 343$ and $\mathrm{C} 57 \mathrm{BL} / 6 \mathrm{~J}$ mice had similar concentrations of renin (J343 vs C57BL/6J: $1.67 \pm 0.86$ vs $1.01 \pm 0.74 \mathrm{ng} / \mathrm{mL})$, angiotensin I (J343 vs C57BL/6J: $829.16 \pm 395.14$ vs $1602.35 \pm 1233.89 \mathrm{pg} / \mathrm{mL}$ ), and aldosterone (J343 vs C57BL/6J: $279.70 \pm 86.90$ vs $276.66 \pm 97.96 \mathrm{pg} / \mathrm{m}$ :), suggesting that the RAAS was unaffected in both mouse lines (Figure 4).

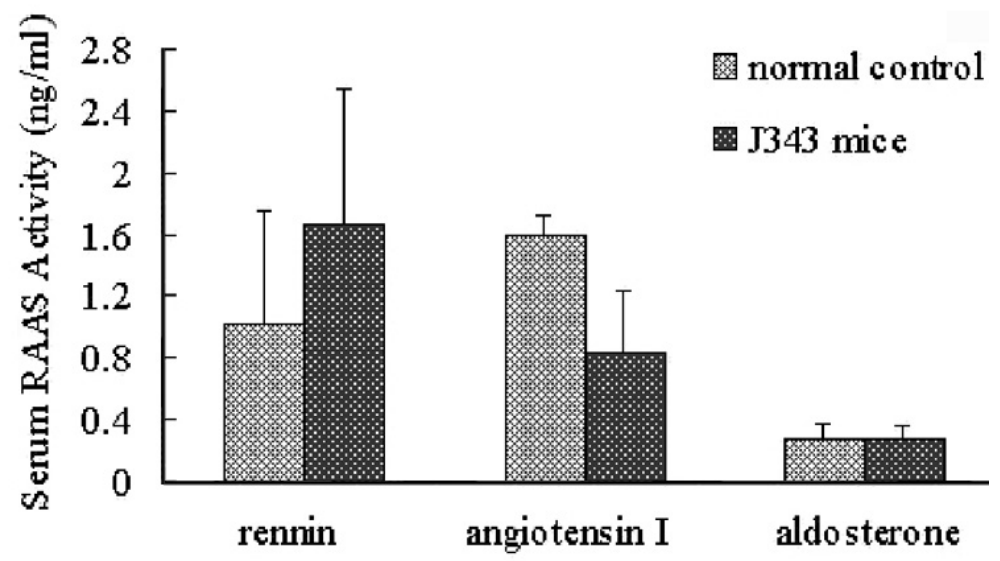

Figure 4. Activity of the plasma renin-angiotensin-aldosterone system (RAAS) in C57BL/6J mice bearing wildtype KCNQ1 and in J343 mice bearing KCNQ1 A340E. Independent $t$ test was applied for data analysis.

\section{DISCUSSION}

KCNQ1 has already been identified in different organs (heart, stomach, kidney, etc.), and is associated with various physiological functions (cardiocyte repolarization, gastric acidification, electrolyte excretion/reabsorption, etc.) (Schroeder et al., 2000; Vallon et al., 2001, 2005; Warth et al., 2002; Lang et al., 2007; Yang et al., 2007; Das et al., 2009; Pan et al., 2010; Amin et al., 2012; Sung et al., 2014). In the mouse kidney, KCNQ1 mRNA is expressed in the PT, DCT, CNT, CD, and glomeruli (Wang, 2004; Zheng et al., 2006). It is also distributed intensely and basolaterally in the DCT and CNT cells (Wang, 2004; Zheng et al., 2006), serving as part of the basolateral potassium channels (Hamilton and Devor, 2012). Recent research results have confirmed that KCNQ1-related potassium channels, which are highly expressed at the apical membrane of proximal convoluted tubule, underlie the $\mathrm{K}^{+}$reabsorption (Wang, 2004). Nevertheless, $\mathrm{Na}^{+}$is reabsorbed from primary urine by the epithelial cells of the thick ascending limb, depending on $\mathrm{Na}^{+}-\mathrm{K}^{+}$-ATPase, which functions properly under the condition of electroneutrality. Basolateral outflow of the $\mathrm{K}^{+}$current by the potassium channel couples with the $\mathrm{Na}^{+}-\mathrm{K}^{+}$-ATPase pump current in order to balance the charge movement across the cell membrane. Thus, the basolateral potassium channel is suggested to maintain the intracellular electroneutrality by $\mathrm{K}^{+}$recycling and plays an essential role in the reabsorption of $\mathrm{Na}^{+}$(Dawson and Richards, 1990; Hamilton and Devor, 2012). Additionally, $\mathrm{K}^{+}$recycling across the membrane of kidney epithelial cells is necessary for the 
continuous function of the $\mathrm{Na}^{+}-\mathrm{K}^{+}-2 \mathrm{Cl}^{-}$cotransporter (NKCC2) (Welling, 1997), suggesting that the basolateral potassium channel plays an important part in $\mathrm{Cl}^{-}$reabsorption.

Compared with the C57BL/6J mice bearing wild-type KCNQ1, excessive urinary electrolyte (potassium, sodium, and chloride) loss characterized the J343 mice bearing KCNQ1 A340E in the present experiments. Because both mouse lines had similar urine volume outputs and glucose contents, this effect of electrolyte loss seems to be independent of water and glucose reabsorption. The loss-of-function KCNQ1 A340E mutation inhibits the transmembrane recycling of $\mathrm{K}^{+}$, which facilitates the high concentration of urinary potassium. Moreover, inhibition of $\mathrm{K}^{+}$recycling decouple the $\mathrm{Na}^{+}-\mathrm{K}^{+}$exchange by $\mathrm{Na}^{+}-\mathrm{K}^{+}$-ATPase and the $\mathrm{Na}^{+}-\mathrm{K}^{+}-2 \mathrm{Cl}^{-}$cotransportation by $\mathrm{NKCC} 2$, respectively. Reabsorption of $\mathrm{Na}^{+}$and $\mathrm{Cl}^{-}$is then abolished. An abnormality of the potassium channel due to KCNQ1 mutation, therefore, could be responsible for the urine-based electrolyte loss.

Except for the potassium channel in the urinary system, a number of KCNQ1-related channels have been recognized in the GIT. In brief, the heterologous assembly of KCNQ1/ KCNE2 dominates the potassium channels in parietal cells of the stomach and then determines the secretion of gastric acid by $\mathrm{H}^{+} / \mathrm{K}^{+}$-ATPase-dependent $\mathrm{K}^{+}$recycling (Dedek and Waldegger, 2001; Pan et al., 2010). Coupling of KCNQ1 and KCNE1 (another member of the KCNE family) in the mouse pancreatic acini leads to a voltage-dependent $\mathrm{K}^{+}$current necessary for electrolyte and enzyme secretion (Warth et al., 2002). Nevertheless, KCNQ1 and KCNE3 are of great importance to the cAMP-regulated $\mathrm{K}^{+}$current and to ion transportation via $\mathrm{NKCC} 2-$ and $\mathrm{Na}^{+}-\mathrm{K}^{+}$-ATPase-based $\mathrm{K}^{+}$recycling (Schroeder et al., 2000). Their functional co-assembly abolishes the depolarization-activated gating of KCNQ1 in the basolateral membrane of colonic and alvine crypt cells (Lohrmann et al., 1995; Dedek and Waldegger, 2001; Vallon et al., 2005). These multiple actions of KCNQ1 highlight its critical role in electrolyte metabolism of the GIT.

As a compensatory effect for the urinary electrolyte loss, the J343 mice demonstrated much more 24-h intake of food containing electrolytes (including $\mathrm{K}^{+}, \mathrm{Na}^{+}$, and $\mathrm{Cl}^{-}$) than did the $\mathrm{C} 57 \mathrm{BL} / 6 \mathrm{~J}$ mice. For the sake of its inhibitory effect on $\mathrm{K}^{+}$recycling, the $\mathrm{A} 340 \mathrm{E}$ mutation of KCNQ1 is supposed to deprive the intestinal epithelial cells of electroneutrality. Both $\mathrm{Na}^{+}-\mathrm{K}^{+}$-ATPase and NKCC2 are subsequently inactivated, which may lead to the incomplete absorption of electrolytes in the food and increased electrolyte loss via the feces. Indeed, fecal loss of $\mathrm{Na}^{+}$and $\mathrm{Cl}^{-}$was another phenotypic feature of these KCNQ1 mutant mice.

The actions of KCNQ1 A340E in the ingestion, absorption, and excretion of different kinds of electrolytes exert great impact on the dynamics of electrolyte metabolism, which was characterized by the dramatic increase in the intake and loss of $\mathrm{K}^{+}, \mathrm{Na}^{+}$, and $\mathrm{Cl}^{-}$by the $\mathrm{J} 343$ mice. A dynamic disturbance of electrolyte metabolism resultantly impairs electrolyte homeostasis in mice. Compared with the C57BL/6J mice, the J343 mice took potassium $(86.35 \pm 27.21 \mu \mathrm{mol} / 24$ h) much more than that of C57BL/6J ones $(57.53 \pm 9.33 \mu \mathrm{mol} / 24 \mathrm{~h})$. But they suffered from even higher level of urinary potassium (J343 vs C57BL/6J: $147.69 \pm 99.00 \mathrm{~h}$ vs $101.66 \pm 36.80$ $\mu \mathrm{mol} / 24 \mathrm{~h}$ ). Statistical down-regulated level of serum $\mathrm{K}^{+}$was then characterized the J343 mice. Conversely, J343 mice took large amount of dietary sodium (J343 vs C57BL/6J: $133.23 \pm 41.98$ vs $88.76 \pm 14.39 \mu \mathrm{mol} / 24 \mathrm{~h}$ ) and chloride (J343 vs $\mathrm{C} 57 \mathrm{BL} / 6 \mathrm{~J}: 230.18 \pm 72.54$ vs $153.36 \pm 24.87$ $\mu \mathrm{mol} / 24 \mathrm{~h}$ ). Their fecal (J343 vs C57BL/6J: $22.40 \pm 15.66$ vs $12.68 \pm 4.54 \mu \mathrm{mol} / 24 \mathrm{~h}$ (sodium); $0.45 \pm 10.68 v s 19.53 \pm 4.90 \mu \mathrm{mol} / 24 \mathrm{~h}$ (chloride)) and urinary loss of electrolyte (J343 vs C57BL/6J: $100.60 \pm 75.57$ vs $67.53 \pm 29.22 \mu \mathrm{mol} / 24 \mathrm{~h}$ (sodium); $122.70 \pm 80.81 \mathrm{~h}$ vs $90.59 \pm$ $35.30 \mu \mathrm{mol} / 24 \mathrm{~h}$ (chloride)) were relative limited. KCNQ1 A340E, therefore, induced significant up-regulation of serum $\mathrm{Na}^{+}$and $\mathrm{Cl}^{-}$concentration.

Genetics and Molecular Research 15 (3): gmr.15038802 
In terms of the possible mechanism, KCNQ1 A340E may alter electrolyte metabolism, and finally electrolyte homeostasis, at its transcriptional, translational, and functional levels (Pan et al., 2010; Choveau and Shapiro, 2012). Both KCNQ1 mRNA and protein levels were therefore tested in the stomach, intestine, cecum, colon-rectum, and kidney of the J343 and $\mathrm{C} 57 \mathrm{BL} / 6 \mathrm{~J}$ mice, revealing no detectable difference between the two mouse lines. Thus, lossof-function, but not reduced expression, is pivotal to the effect of KCNQ1 A340E.

Except for the KCNQ1-related ion transportation, electrolyte homeostasis is now considered to be regulated by some other mechanisms, especially the RAAS. Cascaded activation of renin, angiotensin I, and aldosterone stimulates nephrological reabsorption of $\mathrm{Na}^{+}$and $\mathrm{Cl}^{-}$, whereas inactivation of this system induces the urinary loss of electrolytes. Whether KCNQ1 interacts with the RAAS, and then indirectly affects electrolyte homeostasis, still remains to be solved. According to our radioimmunological observations, both the J343 and C57BL/6J mice show normal activity of the RAAS. Therefore, KCNQ1 mutation, rather than RAAS dysregulation, is indicated to be the underlying cause for the impaired electrolyte homeostasis in J343 mice.

In conclusion, KCNQ1 may serve as the critical regulator of electrolyte metabolism. A loss-of-function mutation, KCNQ1 A340E, is sufficient to induce the fecal and urinary losses of electrolytes and compensatory intake of dietary electrolytes. Disorders in electrolyte metabolism impair the homeostasis of serum electrolytes, which is characterized by the significantly downregulated $\mathrm{K}^{+}$level and upregulated levels of $\mathrm{Na}^{+}$and $\mathrm{Cl}^{-}$. Functionally, KCNQ1 A340E is suggested to affect electrolyte homeostasis independently of RAAS activity.

\section{ACKNOWLEDGMENTS}

Research supported by the State Key Development Program for Basic Research of China (\#2012CB517501), the National Natural Science Foundation (\#81470859, \#81270492, and \#81000173), the Program of the Shanghai Committee of Science and Technology (\#13ZR1426700), the Program of Shanghai Jiaotong university (\#YG2012NS37), and the "Wang Bao En” Research Program for liver fibrosis (\#2010HX002).

\section{REFERENCES}

Amin AS, Giudicessi JR, Tijsen AJ, Spanjaart AM, et al. (2012). Variants in the 3' untranslated region of the KCNQ1encoded Kv7.1 potassium channel modify disease severity in patients with type 1 long QT syndrome in an allelespecific manner. Eur. Heart J. 33: 714-723. http://dx.doi.org/10.1093/eurheartj/ehr473

Casimiro MC, Knollmann BC, Yamoah EN, Nie L, et al. (2004). Targeted point mutagenesis of mouse Kcnq1: phenotypic analysis of mice with point mutations that cause Romano-Ward syndrome in humans. Genomics 84: 555-564. http:// dx.doi.org/10.1016/j.ygeno.2004.06.007

Choveau FS and Shapiro MS (2012). Regions of KCNQ K(+) channels controlling functional expression. Front. Physiol. 3: 397. http://dx.doi.org/10.3389/fphys.2012.00397

Das S, Makino S, Melman YF, Shea MA, et al. (2009). Mutation in the S3 segment of KCNQ1 results in familial lone atrial fibrillation. Heart Rhythm 6: 1146-1153. http://dx.doi.org/10.1016/j.hrthm.2009.04.015

Dawson DC and Richards NW (1990). Basolateral K conductance: role in regulation of $\mathrm{NaCl}$ absorption and secretion. Am. J. Physiol. 259: C181-C195.

Dedek K and Waldegger S (2001). Colocalization of KCNQ1/KCNE channel subunits in the mouse gastrointestinal tract. Pflugers Arch. 442: 896-902. http://dx.doi.org/10.1007/s004240100609

Fröhlich H, Boini KM, Seebohm G, Strutz-Seebohm N, et al. (2011). Hypothyroidism of gene-targeted mice lacking Kcnq1. Pflugers Arch. 461: 45-52. http://dx.doi.org/10.1007/s00424-010-0890-5

Guo CJ, Pan Q, Li DG, Sun H, et al. (2009). miR-15b and miR-16 are implicated in activation of the rat hepatic stellate

Genetics and Molecular Research 15 (3): gmr.15038802 
cell: An essential role for apoptosis. J. Hepatol. 50: 766-778. http://dx.doi.org/10.1016/j.jhep.2008.11.025

Hamilton KL and Devor DC (2012). Basolateral membrane K+ channels in renal epithelial cells. Am. J. Physiol. Renal Physiol. 302: F1069-F1081. http://dx.doi.org/10.1152/ajprenal.00646.2011

Heitzmann D, Grahammer F, von Hahn T, Schmitt-Gräff A, et al. (2004). Heteromeric KCNE2/KCNQ1 potassium channels in the luminal membrane of gastric parietal cells. J. Physiol. 561: 547-557. http://dx.doi.org/10.1113/ jphysiol.2004.075168

Kunzelmann K, Bleich M, Warth R, Levy-Holzman R, et al. (2001a). Expression and function of colonic epithelial KvLQT1 K+ channels. Clin. Exp. Pharmacol. Physiol. 28: 79-83. http://dx.doi.org/10.1046/j.1440-1681.2001.03407.x

Kunzelmann K, Hübner M, Schreiber R, Levy-Holzman R, et al. (2001b). Cloning and function of the rat colonic epithelial K+ channel KVLQT1. J. Membr. Biol. 179: 155-164. http://dx.doi.org/10.1007/s002320010045

Lang F, Vallon V, Knipper M and Wangemann P (2007). Functional significance of channels and transporters expressed in the inner ear and kidney. Am. J. Physiol. Cell Physiol. 293: C1187-C1208. http://dx.doi.org/10.1152/ ajpcell.00024.2007

Lohrmann E, Burhoff I, Nitschke RB, Lang HJ, et al. (1995). A new class of inhibitors of cAMP-mediated Cl- secretion in rabbit colon, acting by the reduction of cAMP-activated K+ conductance. Pflugers Arch. 429: 517-530. http://dx.doi. org/10.1007/BF00704157

Pan Q, Ma J, Zhou Q, Li J, et al. (2010). KCNQ1 loss-of-function mutation impairs gastric acid secretion in mice. Mol. Biol. Rep. 37: 1329-1333. http://dx.doi.org/10.1007/s11033-009-9511-9

Robbins J (2001). KCNQ potassium channels: physiology, pathophysiology, and pharmacology. Pharmacol. Ther. 90: 1-19. http://dx.doi.org/10.1016/S0163-7258(01)00116-4

Sanguinetti MC, Curran ME, Zou A, Shen J, et al. (1996). Coassembly of K(V)LQT1 and minK (IsK) proteins to form cardiac I(Ks) potassium channel. Nature 384: 80-83. http://dx.doi.org/10.1038/384080a0

Schroeder BC, Waldegger S, Fehr S, Bleich M, et al. (2000). A constitutively open potassium channel formed by KCNQ1 and KCNE3. Nature 403: 196-199. http://dx.doi.org/10.1038/35003200

Sung JY, Bae EJ, Park S, Kim SY, et al. (2014). Large deletion in KCNQ1 identified in a family with Jervell and LangeNielsen syndrome. Ann. Lab. Med. 34: 395-398. http://dx.doi.org/10.3343/alm.2014.34.5.395

Vallon V, Grahammer F, Richter K, Bleich M, et al. (2001). Role of KCNE1-dependent K+ fluxes in mouse proximal tubule. J. Am. Soc. Nephrol. 12: 2003-2011.

Vallon V, Grahammer F, Volk1 H, Sandu CD, et al. (2005). KCNQ1-dependent transport in renal and gastrointestinal epithelia. Proc. Natl. Acad. Sci. USA 102: 17864-17869. http://dx.doi.org/10.1073/pnas.0505860102

Wang W (2004). Renal potassium channels: recent developments. Curr. Opin. Nephrol. Hypertens. 13: 549-555. http:// dx.doi.org/10.1097/00041552-200409000-00011

Warth R, Garcia Alzamora M, Kim JK, Zdebik A, et al. (2002). The role of KCNQ1/KCNE1 K(+) channels in intestine and pancreas: lessons from the KCNE1 knockout mouse. Pflugers Arch. 443: 822-828. http://dx.doi.org/10.1007/ s00424-001-0751-3

Welling PA (1997). Primary structure and functional expression of a cortical collecting duct Kir channel. Am. J. Physiol. 273: F825-F836.

Yang Y, Liu Y, Dong X, Kuang Y, et al. (2007). Human KCNQ1 S140G mutation is associated with atrioventricular blocks. Heart Rhythm 4: 611-618. http://dx.doi.org/10.1016/j.hrthm.2007.01.029

Zheng W, Verlander JW, Lynch IJ, Cash M, et al. (2006). Cellular distribution of the potassium channel KCNQ1 in normal mouse kidney. Am. J. Physiol. Renal Physiol. 292: F456-F466. http://dx.doi.org/10.1152/ajprenal.00087.2006

Genetics and Molecular Research 15 (3): gmr.15038802 